Supporting Information

\title{
Scandium-Catalyzed Syndiospecific Copolymerization of Styrene
}

\author{
with Isoprene \\ Hao Zhang ${ }^{\dagger}$, Yunjie Luo ${ }^{\dagger *}$, and Zhaomin Hou* \\ Organometallic Chemistry Laboratory, RIKEN (The Institute of Physical and Chemical Research), \\ Hirosawa 2-1, Wako, Saitama 351-0198 Japan
}

\section{Experimental section}

General Procedures and Materials. All the manipulations were performed under pure argon with rigorous exclusion of air and moisture using standard Schlenk techniques and an Mbraun glovebox. Toluene was distilled from sodium/benzophenone ketyl, degassed by the freeze-pump-thaw method, and stored over fresh Na chips in the glovebox. $\quad\left(\mathrm{C}_{5} \mathrm{Me}_{4} \mathrm{SiMe}_{3}\right) \mathrm{Sc}\left(\mathrm{CH}_{2} \mathrm{SiMe}_{3}\right)_{2}$ (THF) (1) was prepared as described previously. ${ }^{6 a}\left[\mathrm{Ph}_{3} \mathrm{C}\right]\left[\mathrm{B}\left(\mathrm{C}_{6} \mathrm{~F}_{5}\right)_{4}\right]$ was purchased from Tosoh Finechem Corporation and used without purification. Styrene (Kanto Chemical Co., Ltd.) and isoprene (TCI) were dried by stirring with $\mathrm{CaH}_{2}$ for 24 hours, and distilled under reduced pressure prior to polymerization experiments. The deuterated solvents were obtained from ISOTEC.

All ${ }^{1} \mathrm{H}(300 \mathrm{MHz})$ and ${ }^{13} \mathrm{C}(75.5 \mathrm{MHz})$ NMR spectra were recorded on a JEOL JNM-EX 270 spectrometer $\left(300 \mathrm{MHz},{ }^{1} \mathrm{H}\right)$. All deuterated NMR solvents were stored over molecular sieves under a nitrogen atmosphere, and all chemical shifts are given in ppm and are referenced to $\mathrm{Me}_{4} \mathrm{Si} .{ }^{13} \mathrm{C}$ NMR spectra for polystyrene and poly(styrene-co-isoprene)s were recorded on a JEOL JNM-EX 270 spectrometer $\left(75.5 \mathrm{MHz},{ }^{13} \mathrm{C}\right)$ with proton decoupling. The copolymer samples for analysis were prepared by dissolving the polymers in $\mathrm{CDCl}_{3}$ or $1,1,2,2$,-tetrachloroethane- $d_{2}$ solution, and the spectra were measured at $110^{\circ} \mathrm{C}$.

Molecular weight and molecular weight distribution for the copolymer were measured by gel permeation chromatography (GPC, Tosoh HLC-8121GPC/HT) using a RI-8022 detector (for high temperature, Tosoh Co.) with polystyrene gel column (TSK gel $\mathrm{GMH}_{\mathrm{HR}}-\mathrm{H} \mathrm{HT} \times 2.30 \mathrm{~cm} \times 7.8 \mathrm{~mm} \phi$ ID), ranging from $<10^{2}$ to $<2.8 \times 10^{8} \mathrm{MW}$ ) at 140 ${ }^{\circ} \mathrm{C}$ using $o$-dichlorobenzene containing $0.05 \mathrm{wt} / \mathrm{v} \%$ 2,6-di-tert-butyl-p-cresol as the solvent. The molecular weight was calculated by a standard procedure based on the 
calibration with standard polystyrene samples. The DSC measurements were performed on a Seiko EXSTAR 6000 instrument at a rate of $20^{\circ} \mathrm{C} / \mathrm{min}$. GPC/FT-IR measurements were carried out by Idemitsu Kosan Co. Ltd. according to an established procedure.

Preparation of sPS- $\boldsymbol{b}$-PI Diblock Copolymers. In the glove box, $4.8 \mathrm{mg}(10 \mu \mathrm{mol})$ of $\left(\mathrm{C}_{5} \mathrm{Me}_{4} \mathrm{SiMe}_{3}\right) \mathrm{Sc}\left(\mathrm{CH}_{2} \mathrm{SiMe}_{3}\right)_{2}$ (THF) in toluene $(15 \mathrm{~mL})$, and $9.0 \mathrm{mg}(10 \mu \mathrm{mol})$ of $\left[\mathrm{Ph}_{3} \mathrm{C}\right]\left[\mathrm{B}\left(\mathrm{C}_{6} \mathrm{~F}_{5}\right)_{4}\right]$ in toluene $(15 \mathrm{~mL})$ were introduced sequentially at room temperature in a $100 \mathrm{~mL}$ round-bottom glass flask with a stirring bar. A few minutes later, a predetermined amount of styrene was added into the flask. After the styrene was completely consumed, isoprene was added to the slurry reaction mixture. The copolymerization was carried out for a predetermined period of time, and was terminated by addition of $20 \mathrm{~mL}$ of methanol. The resulting mixture was poured into methanol $(200 \mathrm{~mL})$ to precipitate the polymer product. The polymer was collected by filtration and dried under vacuum at $60{ }^{\circ} \mathrm{C}$ to a constant weight.

Preparation of a sPS- $\boldsymbol{b}$-PI- $\boldsymbol{b}$-sPS Triblock Copolymer. In the glove box, $4.8 \mathrm{mg}$ $(10 \mu \mathrm{mol})$ of $\left(\mathrm{C}_{5} \mathrm{Me}_{4} \mathrm{SiMe}_{3}\right) \mathrm{Sc}\left(\mathrm{CH}_{2} \mathrm{SiMe}_{3}\right)_{2}(\mathrm{THF})$ in toluene $(15 \mathrm{~mL})$, and $9.0 \mathrm{mg}(10$ $\mu \mathrm{mol})$ of $\left[\mathrm{Ph}_{3} \mathrm{C}\right]\left[\mathrm{B}\left(\mathrm{C}_{6} \mathrm{~F}_{5}\right)_{4}\right]$ in toluene $(15 \mathrm{~mL})$ were introduced sequentially at room temperature in a $100 \mathrm{~mL}$ round-bottom glass flask with a stirring bar. A few minutes later, a predetermined amount of styrene was added into the flask. After the styrene was completely consumed, isoprene was added to the slurry reaction mixture. After the isoprene was completely consumed, a predetermined amount of styrene was added into the flask. The copolymerization was carried out for a predetermined period of time, and was terminated by addition of $20 \mathrm{~mL}$ of methanol. The resulting mixture was poured into methanol $(200 \mathrm{~mL})$ to precipitate the polymer product. The polymer was collected by filtration and dried under vacuum at $60{ }^{\circ} \mathrm{C}$ to a constant weight.

Preparation of Multi-Block Styrene-Isoprene Copolymers. In the glove box, 10 $\mathrm{mg}(21 \mu \mathrm{mol})$ of $\left(\mathrm{C}_{5} \mathrm{Me}_{4} \mathrm{SiMe}_{3}\right) \mathrm{Sc}\left(\mathrm{CH}_{2} \mathrm{SiMe}_{3}\right)_{2}(\mathrm{THF})$ in toluene $(15 \mathrm{~mL})$, and $19 \mathrm{mg}$ $(21 \mu \mathrm{mol})$ of $\left[\mathrm{Ph}_{3} \mathrm{C}\right]\left[\mathrm{B}\left(\mathrm{C}_{6} \mathrm{~F}_{5}\right)_{4}\right]$ in toluene $(10 \mathrm{~mL})$ were introduced sequentially at room temperature in a $100 \mathrm{~mL}$ round-bottom glass flask with a stirring bar. A few minutes later, a mixture of styrene and isoprene was added into the flask. The polymerization proceeded for a predetermined period of time, and was terminated by addition of $20 \mathrm{~mL}$ of methanol. The resulting mixture was poured into methanol $(400 \mathrm{~mL})$ to precipitate copolymer. The copolymer was collected by filtration and dried under vacuum at $60{ }^{\circ} \mathrm{C}$ to a constant weight. 


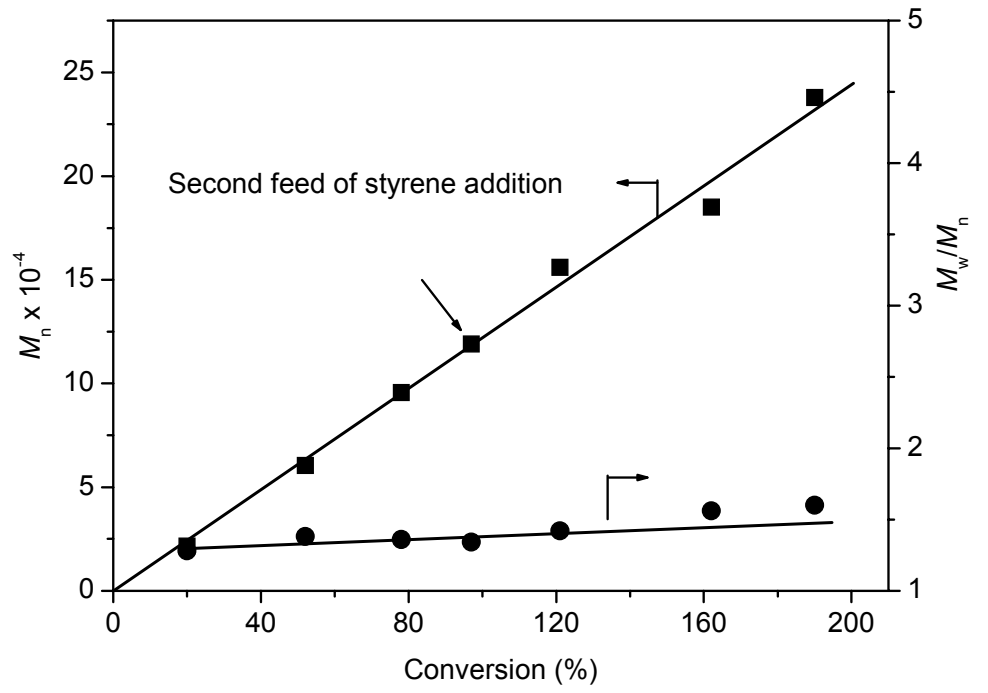

SFigure 1. Plots of $M_{\mathrm{n}}(\boldsymbol{\square})$ and $M_{\mathrm{w}} / M_{\mathrm{n}}(\bullet)$ as a function of styrene conversion for the two-step styrene addition experiment $\left(25^{\circ} \mathrm{C}\right.$; styrene, $21 \mathrm{mmol}$; Sc, $\left.21 \mu \mathrm{mol}\right)$

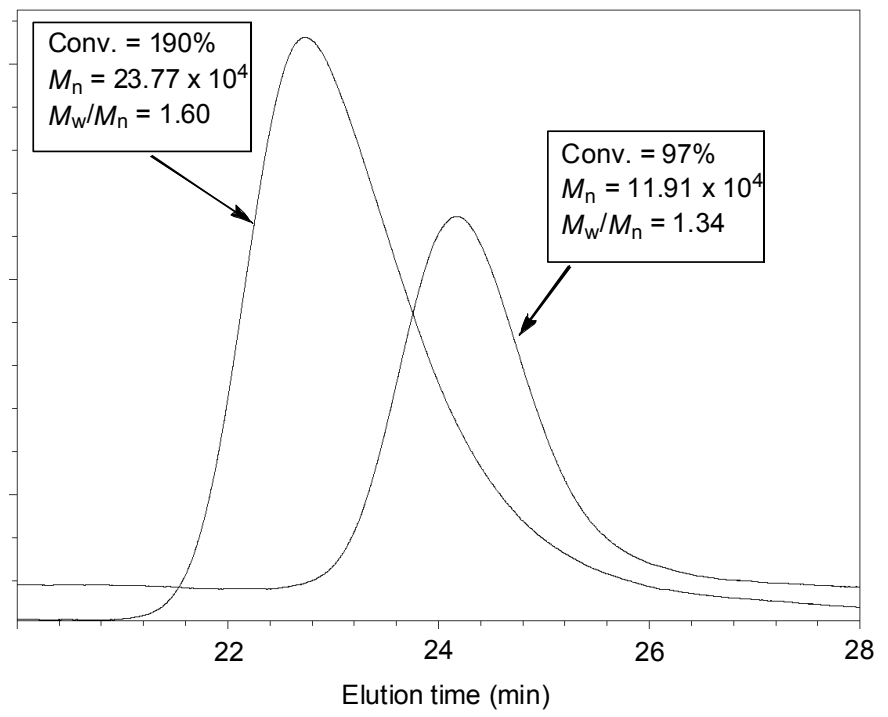

sFigure 2. GPC curves of polystyrenes obtained at different styrene conversions 


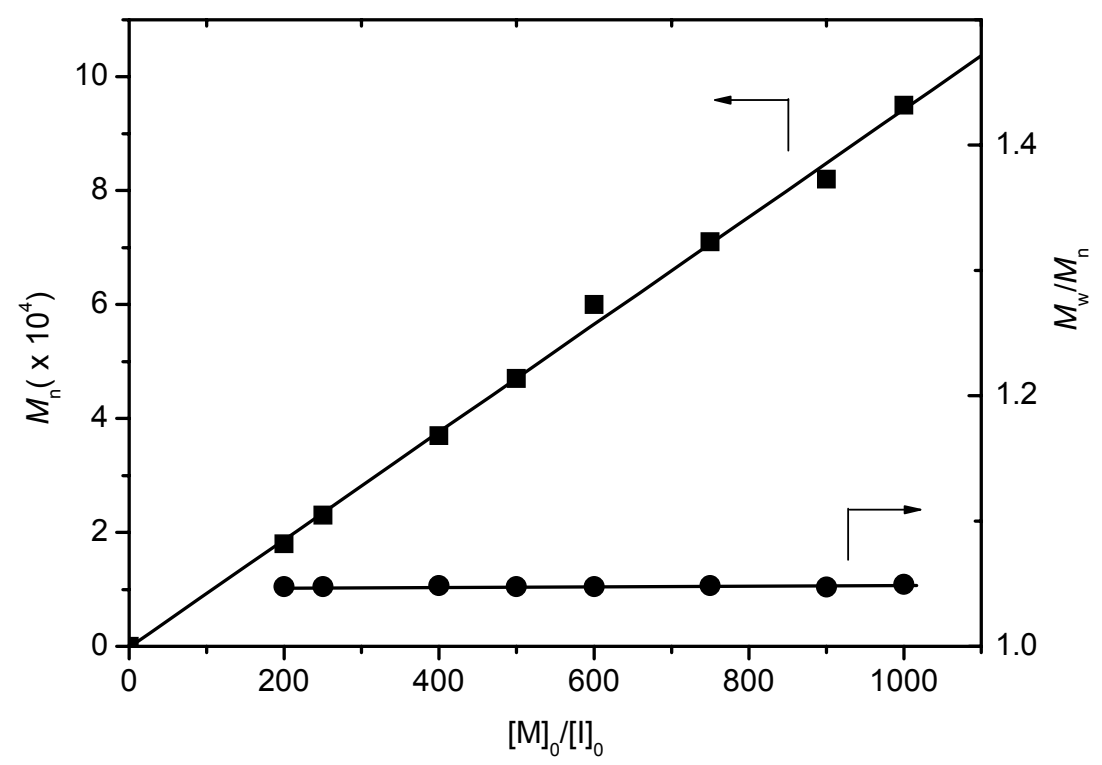

SFigure 3. Plots of dependence of $M_{\mathrm{n}}(\boldsymbol{\bullet})$ and $M_{\mathrm{w}} / M_{\mathrm{n}}(\bullet)$ values on $[\mathrm{M}]_{\mathrm{o}} /[\mathrm{I}]_{\mathrm{o}}$ in polymerization of isoprene at $25^{\circ} \mathrm{C}$. 
STable 1. Living polymerization of isoprene by

$\mathrm{C}_{5} \mathrm{Me}_{4} \mathrm{SiMe}_{3} \mathrm{Sc}\left(\mathrm{CH}_{2} \mathrm{SiMe}_{3}\right)_{2}(\mathrm{THF})(\mathbf{1}) /\left[\mathrm{Ph}_{3} \mathrm{C}\right]\left[\mathrm{B}\left(\mathrm{C}_{6} \mathrm{~F}_{5}\right)_{4}\right]$

\begin{tabular}{|c|c|c|c|c|c|c|c|c|}
\hline run & $\mathrm{Ln}$ & {$[M] /[L n]$} & $\begin{array}{c}t \\
\text { (h) }\end{array}$ & $\begin{array}{c}\text { conv }^{b} \\
(\%)\end{array}$ & $\begin{array}{c}\text { structure }^{d} \\
\text { total } 1,4- \\
(\%)\end{array}$ & $\begin{array}{l}3,4- \\
(\%)\end{array}$ & $\begin{array}{l}M_{\mathrm{n}}^{e} \\
\times 10^{-4}\end{array}$ & $M_{\mathrm{w}} / M_{\mathrm{n}}^{e}$ \\
\hline 1 & $\mathrm{Sc}$ & 200 & 4 & 100 & 34 & 66 & 1.8 & 1.05 \\
\hline 2 & $\mathrm{Sc}$ & 250 & 4 & 99 & 36 & 64 & 2.3 & 1.05 \\
\hline 3 & $\mathrm{Sc}$ & 400 & 4 & 99 & 39 & 61 & 3.7 & 1.09 \\
\hline 4 & $\mathrm{Sc}$ & 500 & 4 & 99 & 38 & 62 & 4.7 & 1.05 \\
\hline 5 & $\mathrm{Sc}$ & 600 & 4 & 99 & 39 & 61 & 6.0 & 1.05 \\
\hline 6 & $\mathrm{Sc}$ & 750 & 4 & 98 & 37 & 63 & 7.1 & 1.07 \\
\hline 7 & $\mathrm{Sc}$ & 900 & 4 & 97 & 40 & 60 & 8.2 & 1.04 \\
\hline 8 & $\mathrm{Sc}$ & 1000 & 4 & 97 & 40 & 60 & 9.5 & 1.09 \\
\hline
\end{tabular}

Weight of polymer obtained/weight of monomer used. ${ }^{c}$ Given in $\mathrm{kg}$ of polymer/(mol Sc.h). ${ }^{d}$ Determined by ${ }^{1} \mathrm{H}$ NMR. ${ }^{e}$ Determined by GPC in THF against polystyrene standard. 


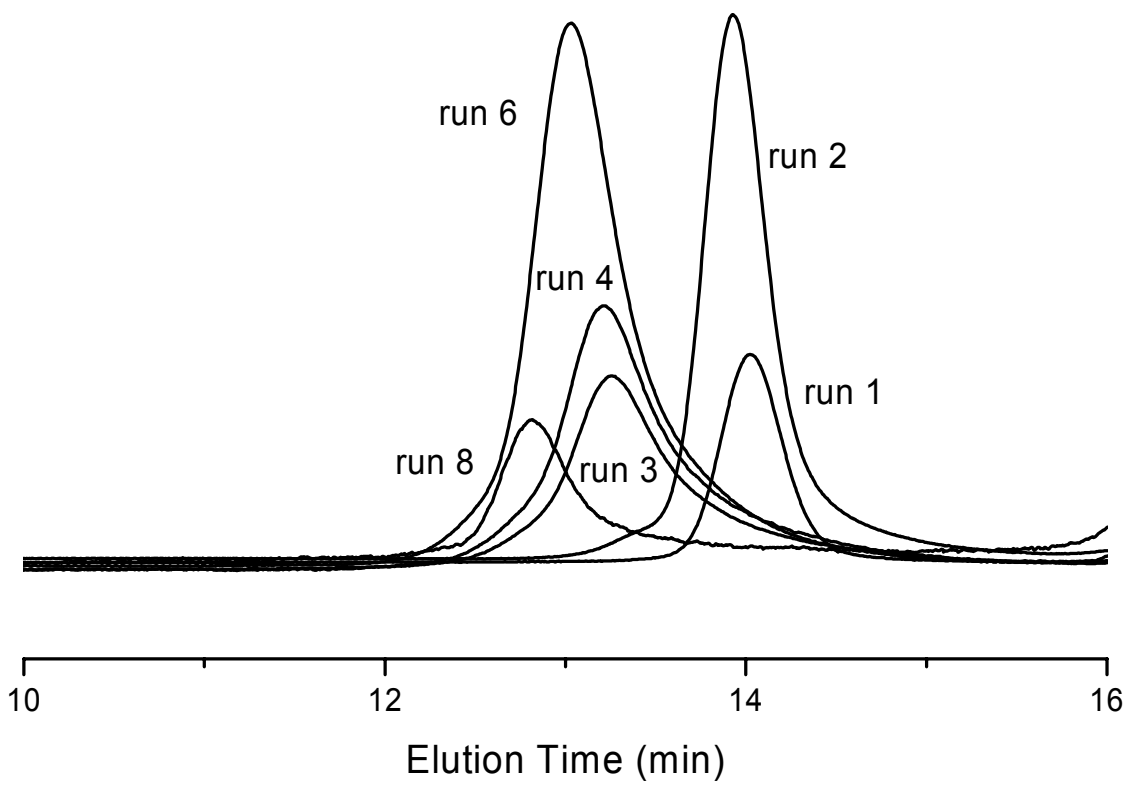

sFigure 4. GPC curves for Living polymerization of isoprene by using half-sandwich scandium complexes $\left(\mathrm{C}_{5} \mathrm{Me}_{4} \mathrm{Si}\left(\mathrm{CH}_{3}\right)_{3} \mathrm{Sc}\left(\mathrm{CH}_{2} \mathrm{SiMe}_{3}\right)_{2}(\mathrm{THF})(\mathbf{1}) /\left[\mathrm{Ph}_{3} \mathrm{C}\right]\left[\mathrm{B}\left(\mathrm{C}_{6} \mathrm{~F}_{5}\right)_{4}\right]\right.$ 

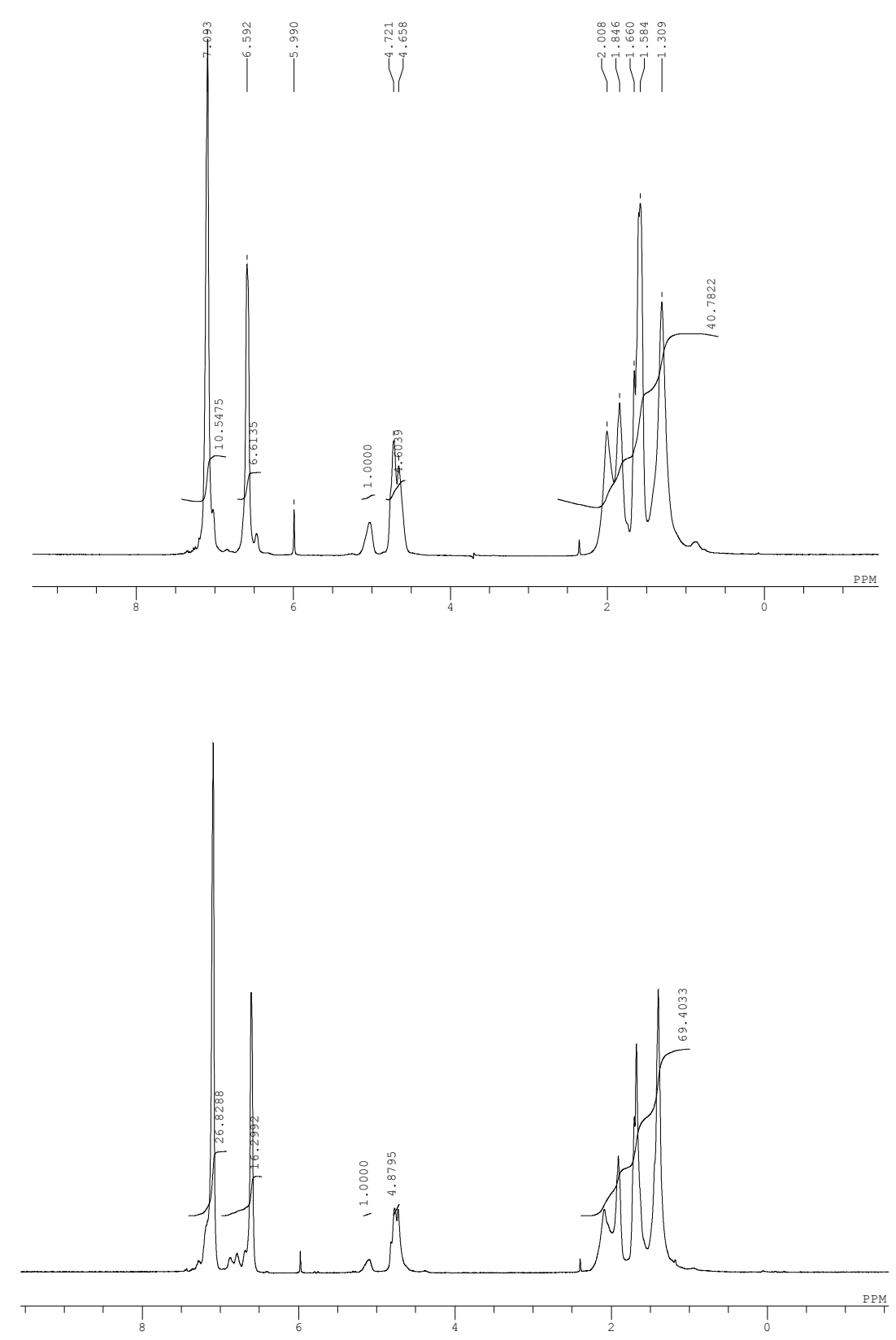

sFigure 5. ${ }^{1} \mathrm{H}$ NMR spectra of styrene-isoprene di-block copolymers (Table 1, run 5 and run 9) 


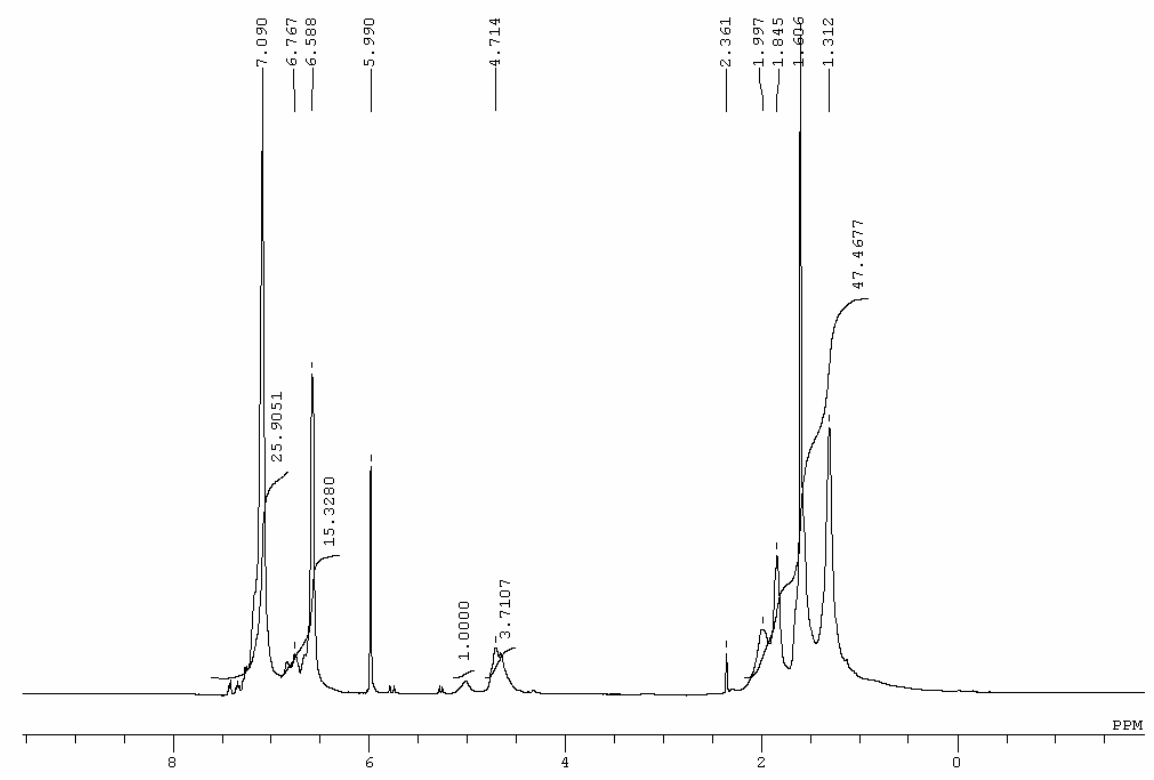

sFigure 6. ${ }^{1} \mathrm{H}$ NMR spectrum of a styrene-isoprene multi-block copolymer (Table 2, run 6.) 


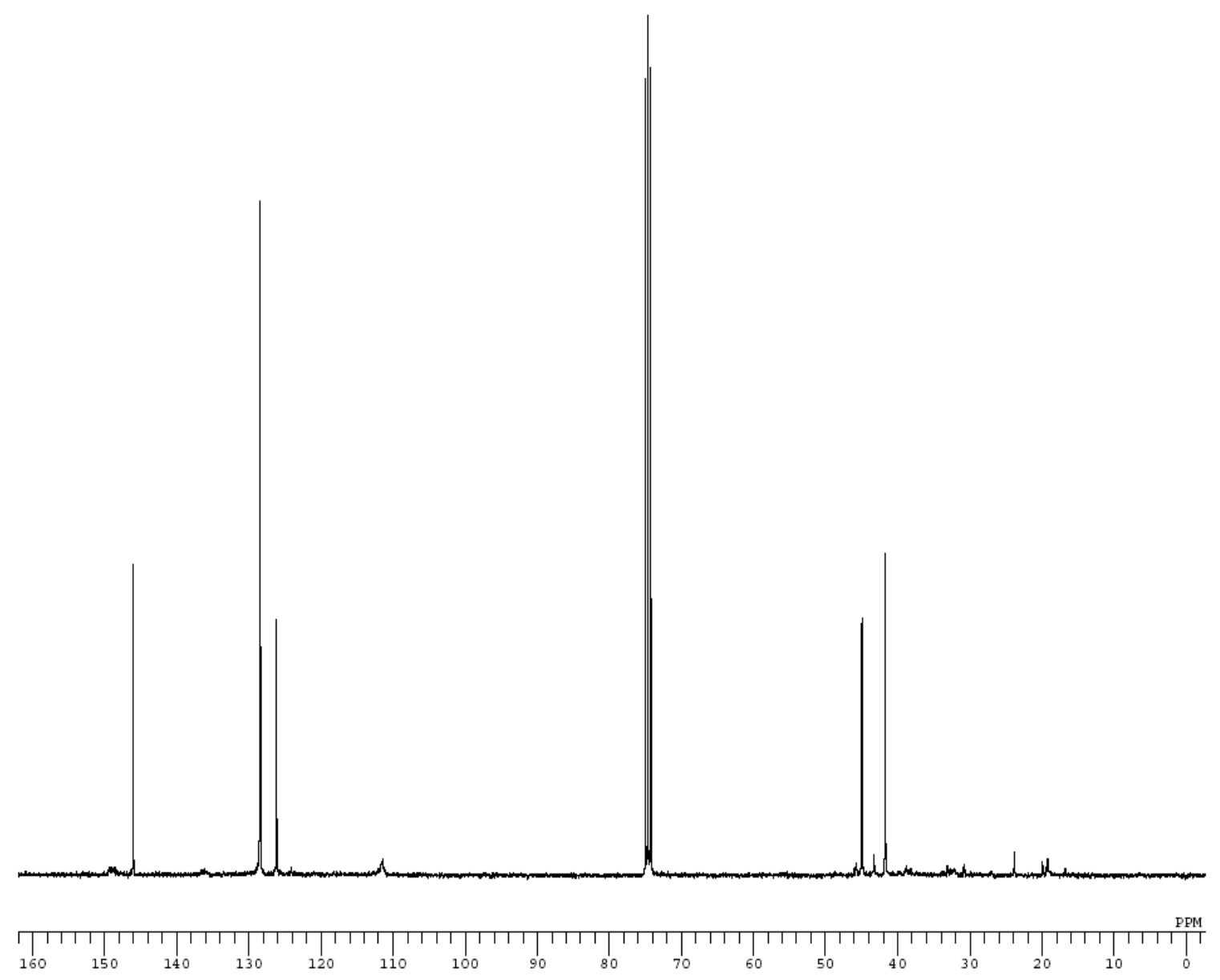

sFigure 7. ${ }^{13} \mathrm{C}$ NMR spectrum of a styrene-isoprene tri-block copolymer (Table 1, run 9) 


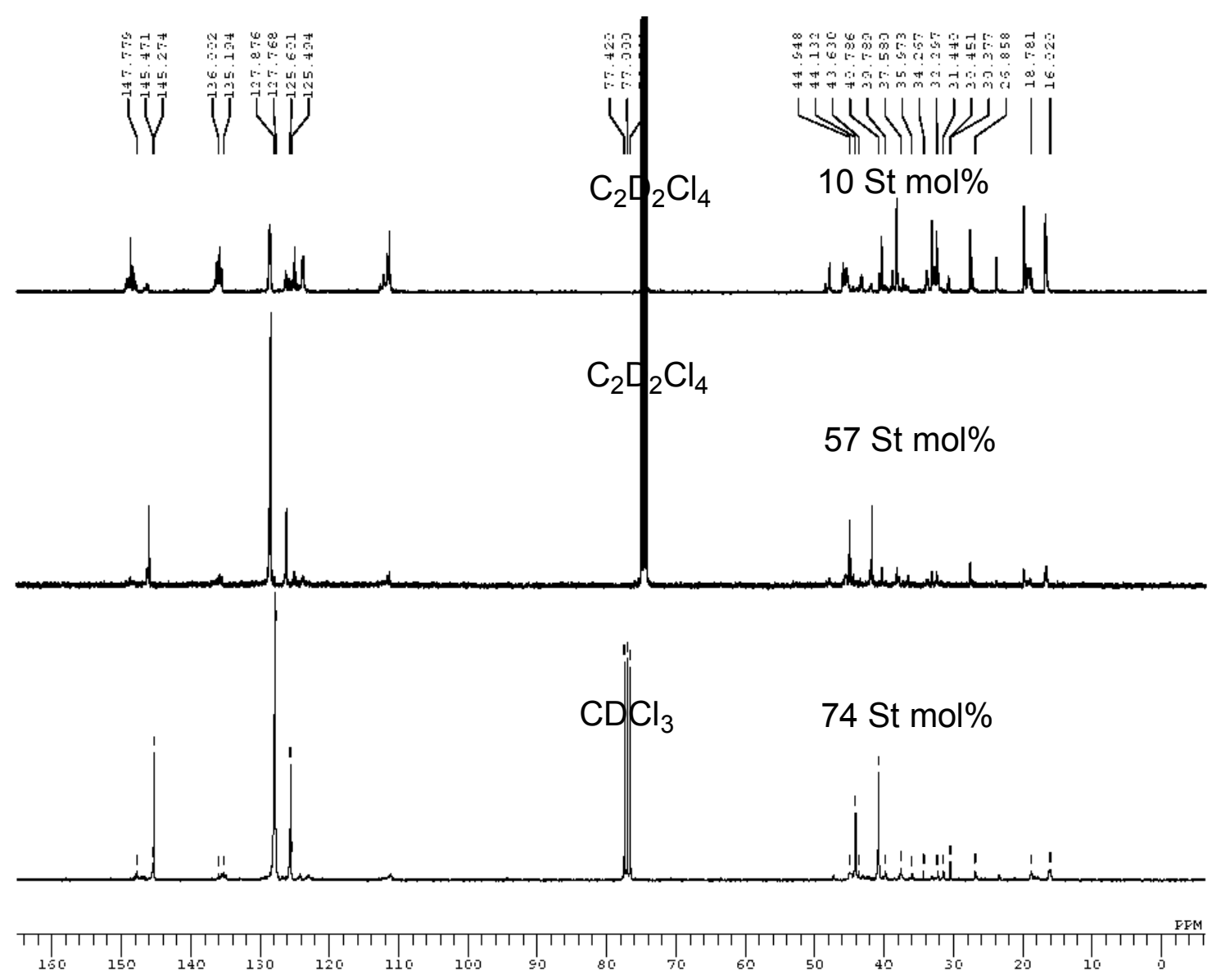

sFigure 8. ${ }^{13} \mathrm{C}$ NMR spectra of styrene-isoprene copolymers having different styrene contents (Table 2, runs 2, 3, 4). 


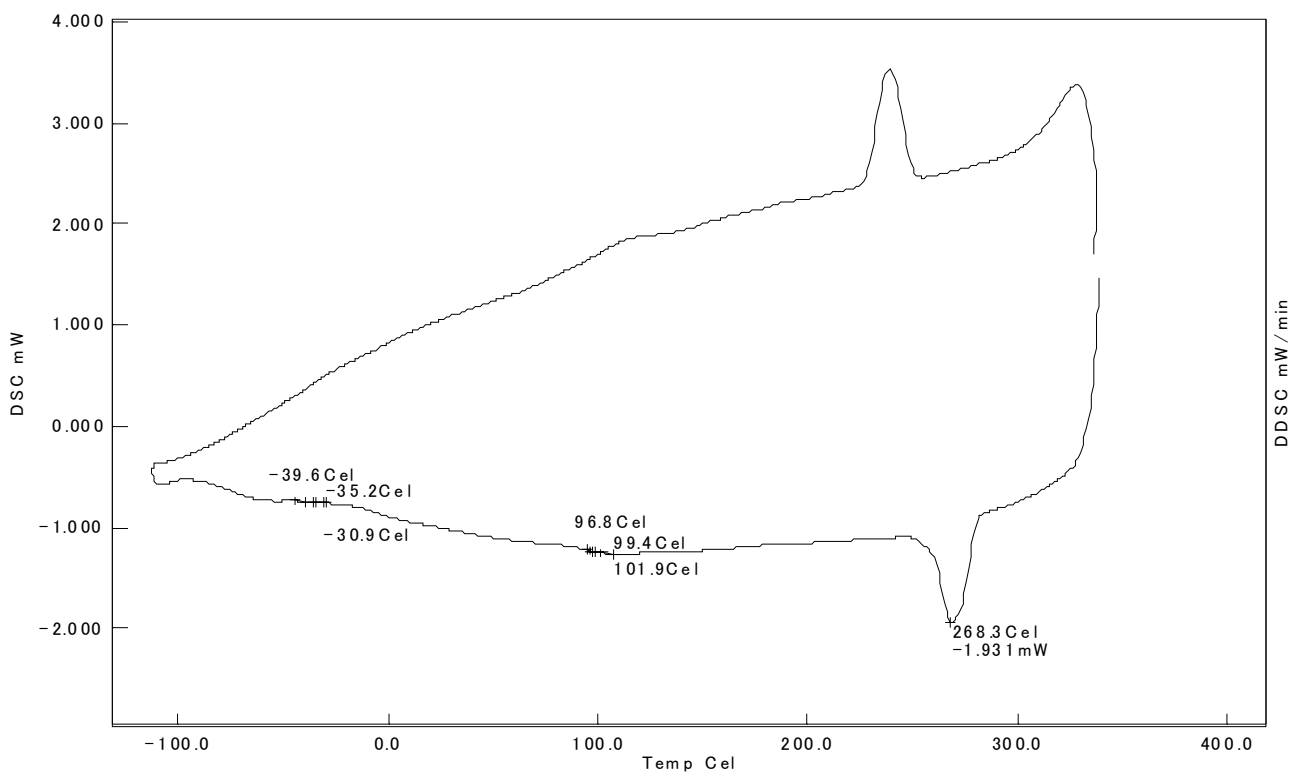

sFigure 9. DSC curve of a styrene-isoprene di-block copolymer sample (Table 1, run 5). 

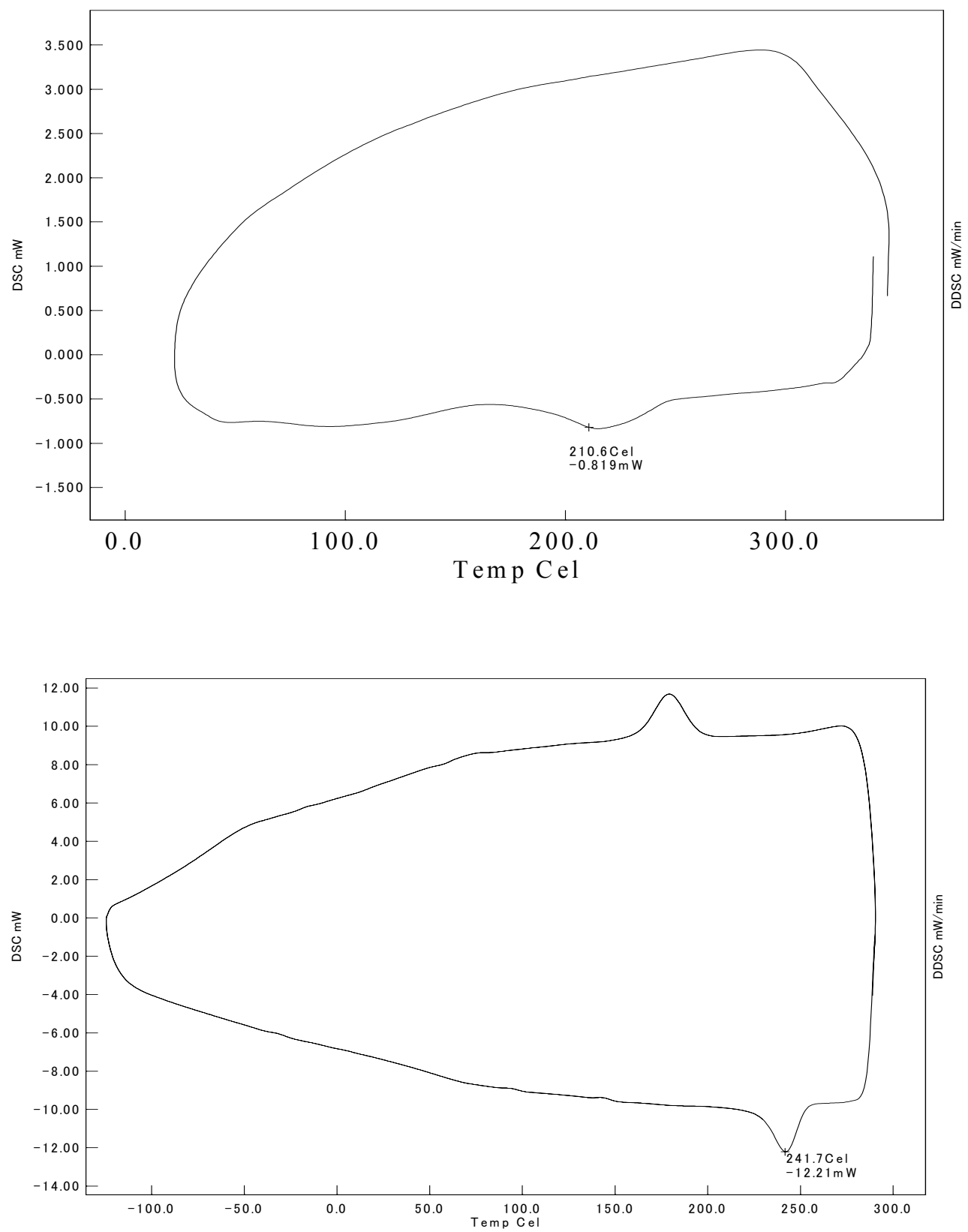

sFigure 10. DSC curves of multi-block styrene-isoprene copolymer samples (Table 2, run 2 (top) and run 6 (bottom)). 


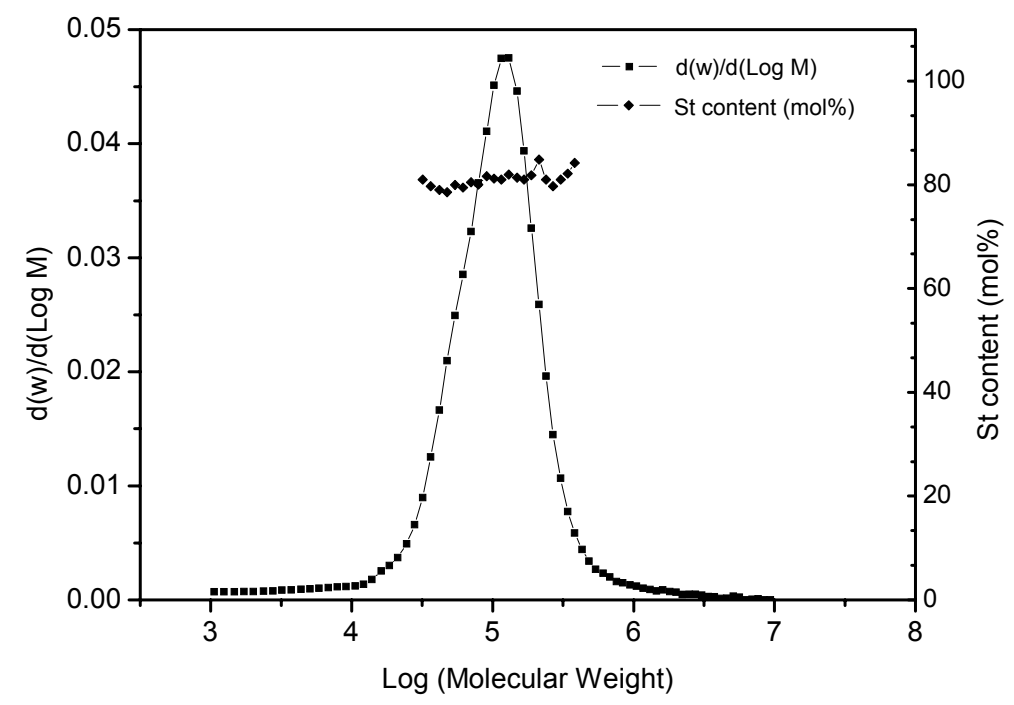

sFigure 11. GPC/FT-IR spectrum of styrene-isoprene copolymer sample (Table 2, run 3). 


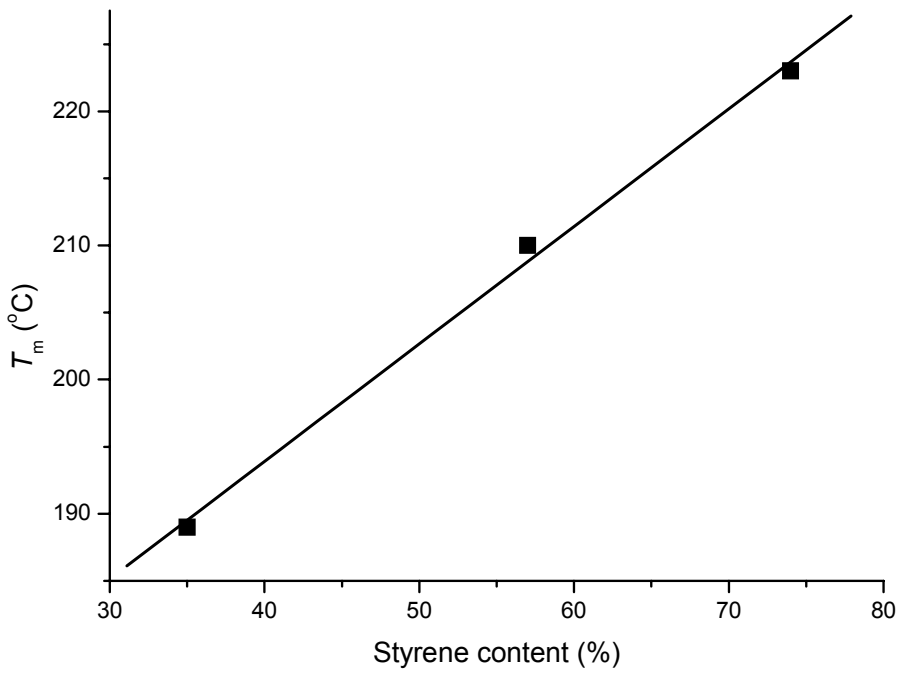

sFigure 12. Plots of $T_{\mathrm{m}} v s$ styrene contents (mol \%) of the multi-block copolymers (Table 2). 